\title{
NOTES ON THE NESTING BEHAVIOR OF THE BETHYLID WASP, EPYRIS ERIOGONI KIEFFER, IN SOUTHERN TEXAS
}

\author{
By William L. Rubink ${ }^{1}$ and Howard E. Evans \\ Department of Zoology and Entomology \\ Colorado State University \\ Fort Collins, Colorado 80523
}

In spite of its cosmopolitan distribution and large size, the family Bethylidae remains relatively poorly known, especially from a behavioral viewpoint. This is particularly unfortunate because of the presumed phylogenetic importance of this group (e.g., Malyshev, 1968) and a growing appreciation of the possible value of these wasps in biological control (e.g., Yamada, 1955; Schaefer, 1962; Gordh, 1976; Gordh and Evans, 1976). Evidently there is a great diversity in the behavior of members of this family. (For reviews see Richards, 1939; Yamada, 1955; Evans, 1964; Gordh, 1976). The present paper concerns a species exhibiting behavior remarkably similar to that of some of the more generalized fossorial wasps of the families Sphecidae and Pompilidae.

The genus Epyris, one of the largest in the family, is found in all zoogeographic regions. They are small wasps $(2-10 \mathrm{~mm}$ in length) and have been little studied aside from a brief report by Bridwell (1917), and a somewhat more detailed account by Williams (1919). Bridwell observed a female of a South African species carrying a tenebrionid larva. Williams studied the Hawaiian species E. extraneus Bridwell, also a predator on tenebrionid larvae, and described stinging behavior, prey carriage, larval development, and certain aspects of its nesting behavior. $\mathrm{He}$ found that prey were hunted and stung before a nest site was selected, and were dragged to the nest site using what Williams described as a unique form of carriage, "the prey being borne rapidly along on the wasp's back".

Our studies are the first conducted on a North American species of Epyris and confirm Williams' observations while adding some details. They were conducted on the shores of the Rio Grande, approximately one mile west of the Bentsen-Rio Grande State Park,

${ }^{1}$ Present address: Department of Entomology, Ohio Agricultural Research and Development Center, Wooster, Ohio 44691.

Manuscript received by the editor February 26, 1980. 
Hidalgo County, Texas, on May 19, 27, and 28, 1979. E. eriogoni Kieffer males and females were common in sandy, bare areas among the vegetation within 10-20 meters of the shoreline (Fig. 1). Males, in loose aggregations, were observed to be active from mid-morning to early afternoon. They were observed to fly just above the soil surface, landing and digging occasionally, and seemed to stray little from an area of a few square meters. Females were most abundant in areas where males were observed; however, no copulations were seen. Other females were observed primarily on low-lying vegetation. In most cases the females flew little. Most of their activity was devoted to scurrying along the soil surface, entering cracks and crevices, or exploring under clods of earth and other debris scattered on the soil surface. Female activity was restricted to early to mid morning hours; few were observed in the afternoon.

Two field observations were made of E. eriogoni nesting behavior. At 1030 hours, May 19, we observed a female carrying its tenebrionid prey up a slight incline in a bare expanse of beach sand. Prey transport consisted of pulling the prey backwards over the sand (Fig. 2a), or carrying it alongside, and sometimes slightly above (Fig. 2b).

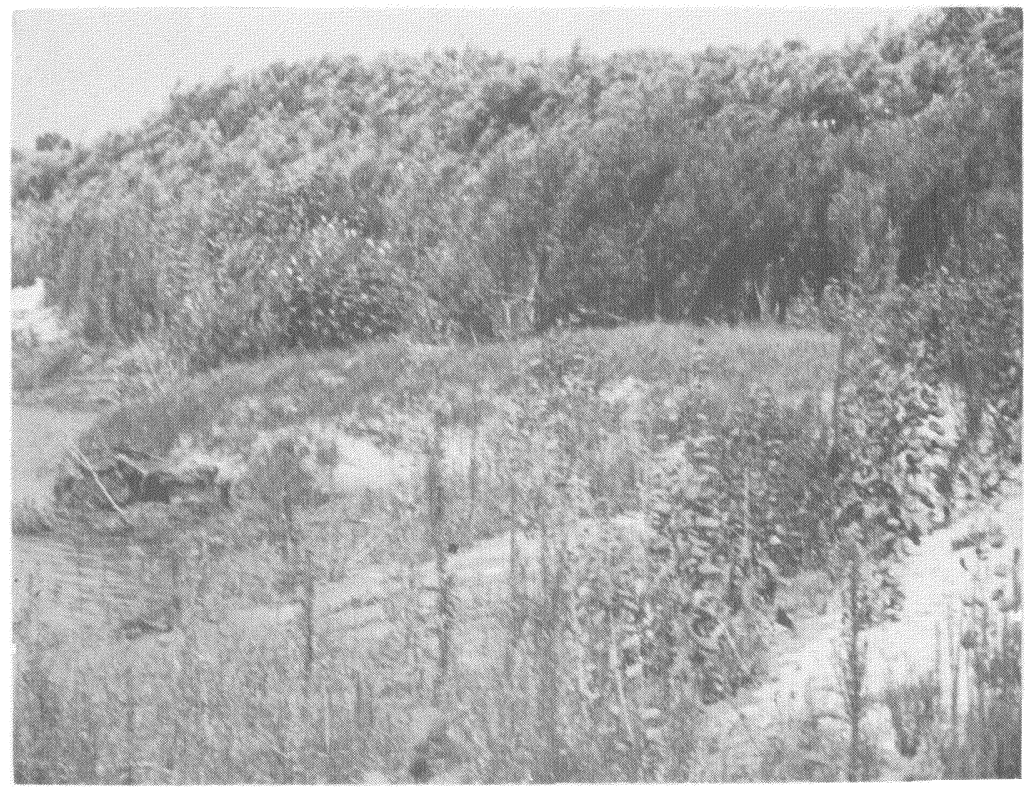

Fig. 1. Typical nesting habitat of Epyris eriogoni in southern Texas. 
In both cases the wasp grasped the larva in the head region, apparently by the palps. A similar mode of transport was described by Williams (1919) for E. extraneus in Hawaii.

After experiencing much difficulty in carrying the relatively larger prey the wasp carried it under a clod of sand. She emerged after approximately one minute and was captured and preserved. Subsequent excavation recovered the prey at about $1 \mathrm{~cm}$ depth. Since no egg was found on the prey, we hypothesize that this site probably represented a temporary location to be utilized until a suitable nest site could be found.

At $0930 \mathrm{hrs}$ on May 28 a second female, E. eriogoni, was observed dragging its larval tenebrionid prey up a gradual sandy.incline. Again the same two forms of prey carriage were noted (Fig. 2). The wasp abandoned the prey several times and, in a 50 to $100 \mathrm{~cm}$ radius, investigated numerous cracks and depressions in the soil surface. She appeared to experience some difficulty in relocating the prey after each of these forays. On the third foray the bethylid entered a tiny hole in the sand (which later proved to be the temporarily closed burrow of a sand wasp), remained several seconds, and then returned directly to the prey and began transporting it towards the hole. Upon reaching the burrow, she deposited the prey outside, a few millimeters distant, and entered the burrow. Within a few seconds she reemerged, grasped the head (palps?) of the prey, and backed into the burrow with it. Shortly after the prey and bethylid had disappeared into the burrow, a Bembix troglodytes entered the same burrow with its dipterous prey; this caused the bethylid to leave the burrow momentarily. After re-entering the burrow the bethylid remained for at least two hours (until 1200 hours), when observations were discontinued.

Excavation of the sand wasp nest revealed a small horizontal tunnel (approx. 1-2 mm diam.) leading off at a right angle from the sand wasp burrow. It extended about two centimeters where it enlarged to a "C" shaped cell only slightly larger than the partially curled tenebrionid prey it contained. The Epyris "nest" was located at approximately $25 \mathrm{~cm}$ depth and immediately before the internal closure of the sand wasp nest (leading to the cell of the latter nest). The female bethylid was not found in the nest. The prey contained a single egg (Fig. 3) in a position nearly identical to that pictured for $E$. extraneus in Hawaii (Williams, 1919). The egg died before hatching.

The two preserved tenebrionid larvae were identified as Blastinus sp., which are apparently very close taxonomically to the prey 


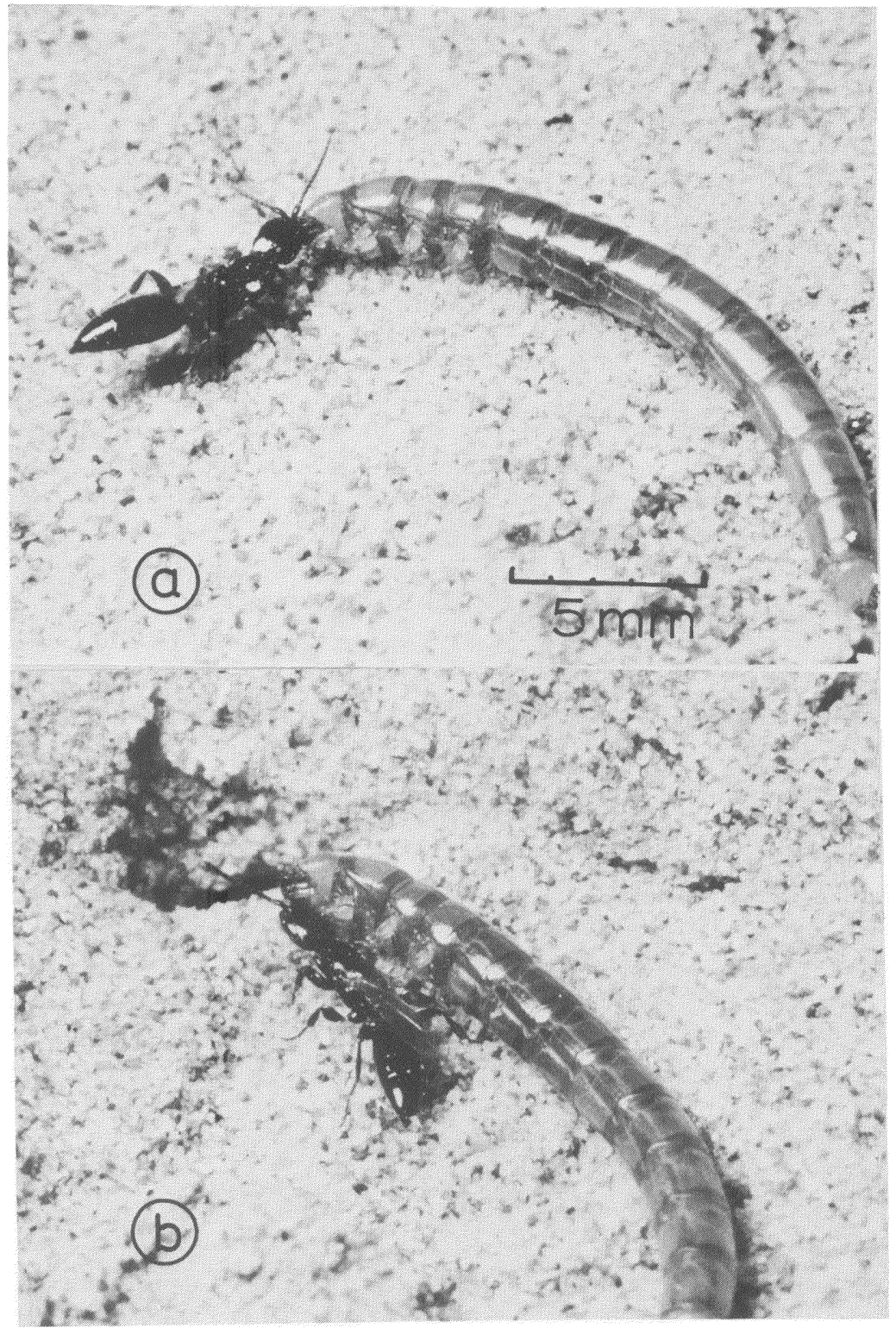

Fig. 2. Epyrus eriogoni dragging its Blastinus sp. prey: a) backwards along the soil surface, and b) forward along the soil surface and toward the nest opening. 


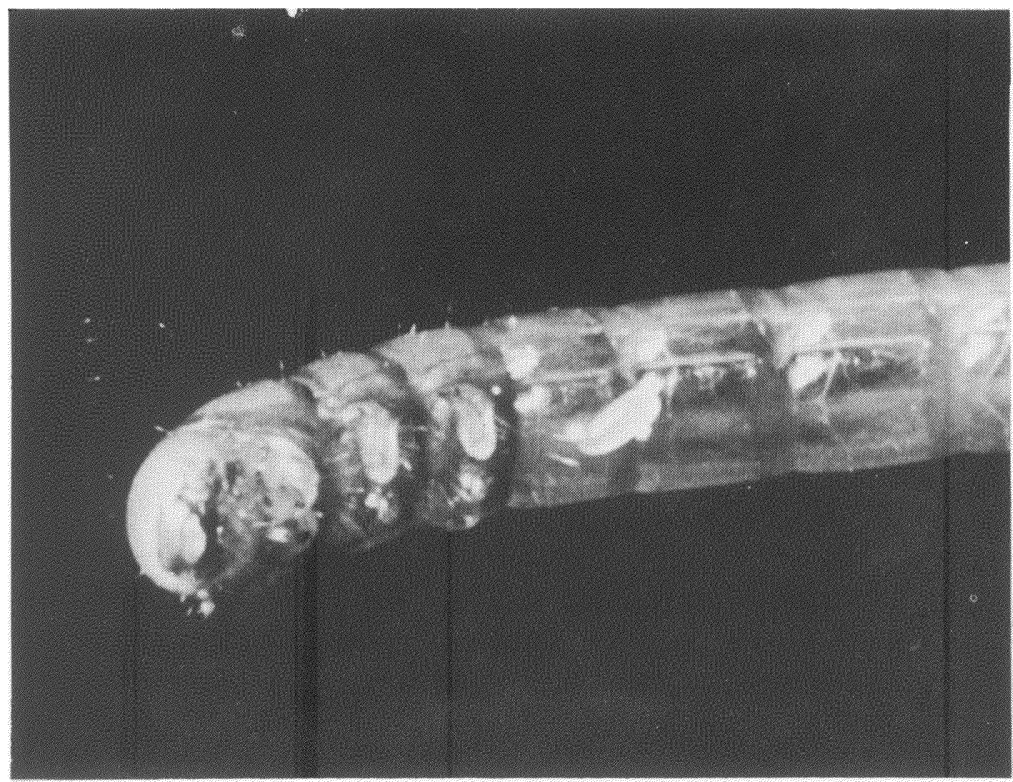

Fig. 3. Blastinus sp. larval prey of Epyris eriogoni showing egg on the first abdominal segment.

(Gonocephalum seriatum (Boisduval)) Williams (1919) found to be used by E. extraneus (T. J. Spilman, pers. comm.).

Four female and five male wasps were returned to the laboratory in an attempt to further study their biology. The males survived for several days and the females for a period of two months on a $5 \%$ honey-water diet. Captive females would not accept Tenebrio molitor L. larvae of the appropriate size class as prey. Although they did appear to be searching for prey in the available cracks and crevices in the rearing chamber, no interest in mealworms was apparent.

\section{Discussion}

Based on this report and that of Williams (1919), the habits of Epyris are seen to parallel remarkably those of some of the primitive fossorial wasps. Certain Pompilidae, for example, commonly build cells from the sides of digger wasp burrows (e.g., Evans, 1974) and some Sphecidae of genera such as Chlorion regularly nest from pre-existing burrows (e.g., Peckham and Kurczewski, 1978). Man- 
dibular prey carriage over the ground also occurs in both of these families, and the manner of dragging the prey backward (Fig. 2a) is remarkably like that of many Pompilidae. Williams was, however, correct in characterizing carriage such as that shown in Figure $2 b$ as unique.

Members of other genera of Bethylidae are known to carry their prey to a second site for oviposition after being stung; this includes Bethylus, Holepyris, Parascleroderma, and to a certain extent Allepyris (Yamada, 1955). However, only Epyris actually constructs a nest. Further work regarding the comparative ethology of Epyris, as well as other members of this family should prove very rewarding.

\section{ACKNOWLEDGMENTS}

This work was partially supported by National Science Foundation grants DEB75-17142 and BNS78-17818 to Howard E. Evans. We thank T. J. Spilman of the USDA Systemic Entomology Laboratory for identifying the tenebrionid larvae.

\section{Literature Cited}

BRIDWELl, J. C.

1917. A note on Epyris (Hymenoptera, Bethylidae) and its prey. Proc. Haw. Ent. Soc. III(4):262-263.

1919. Some notes on Hawaiian and other Bethylidae (Hymenoptera) with the description of a new genus and species. 2nd paper. Proc. Haw. Ent. Soc. IV(2):291-314.

Evans, H. E.

1964. A Synopsis of the American Bethylidae (Hymenoptera, Aculeata). Bull. Mus. Comp. Zool. 132(1):1-222.

1974. Digger wasps as colonizers of new habitat. J. N.Y. Ent. Soc. 82(4):259-67.

1978. The Bethylidae of America north of Mexico. Mem. Am. Ent. Inst. No. 27. $332 \mathrm{pp}$.

GORDH, G.

1976. Goniozus gallicola Fouts, a parasite of moth larvae, with notes on other bethylids: (Hymenoptera: Bethylidae, Lepidoptera, Gelechiidae). U.S.D.A. Tech. Bull. 1524, 27 pp.

Gordh, G. AND H. E. Evans

1976. A new species of Goniozus imported into California from Ethiopia for the biological control of pink bollworm and some notes on the taxonomic status of Parasierola and Goniozus (Hymenoptera: Bethylidae). Proc. Ent. Soc. Wash. 78(4):479-89.

Malyshev, S. I.

1968. Genesis of the Hymenoptera and the Phases of their Evolution. Methuen \& Co., Ltd., London. 319 pp. 
Peckham, D. J. And F. Kurczewski

1978. Nesting behavior of Chlorion aeriarium. Ann. Ent. Soc. Am. 71(5):75861.

RICHARDS, O.W.

1939. The British Bethylidae. Trans. Roy. Ent. Soc. London. 89(8):185-344.

SCHAEFER, C. $\mathrm{H}$.

1962. Life history of Conophthorus radiatae (Coleoptera: Scolytidae) and its principal parasite, Cephalonomia utahensis (Hymenoptera: Bethylidae). Ann. Ent. Soc. Am. 55(5):569-77.

WiLliams, F. X.

1919. Epyris extraneus Bridwell (Bethylidae), a fossorial wasp that preys on the larva of the tenebrionid beetle, Gonocephalum seriatum (Boisduval). Proc. Haw. Ent. Soc. IV(1):55-63.

YAMADA, YASUII

1955. Studies on the natural enemy of the woollen pest, Anthrenus verbaci Linne (Allepyris microneurus Kieffer) (Hymenoptera, Bethylidae). Mushi. 28(3):13-29. 

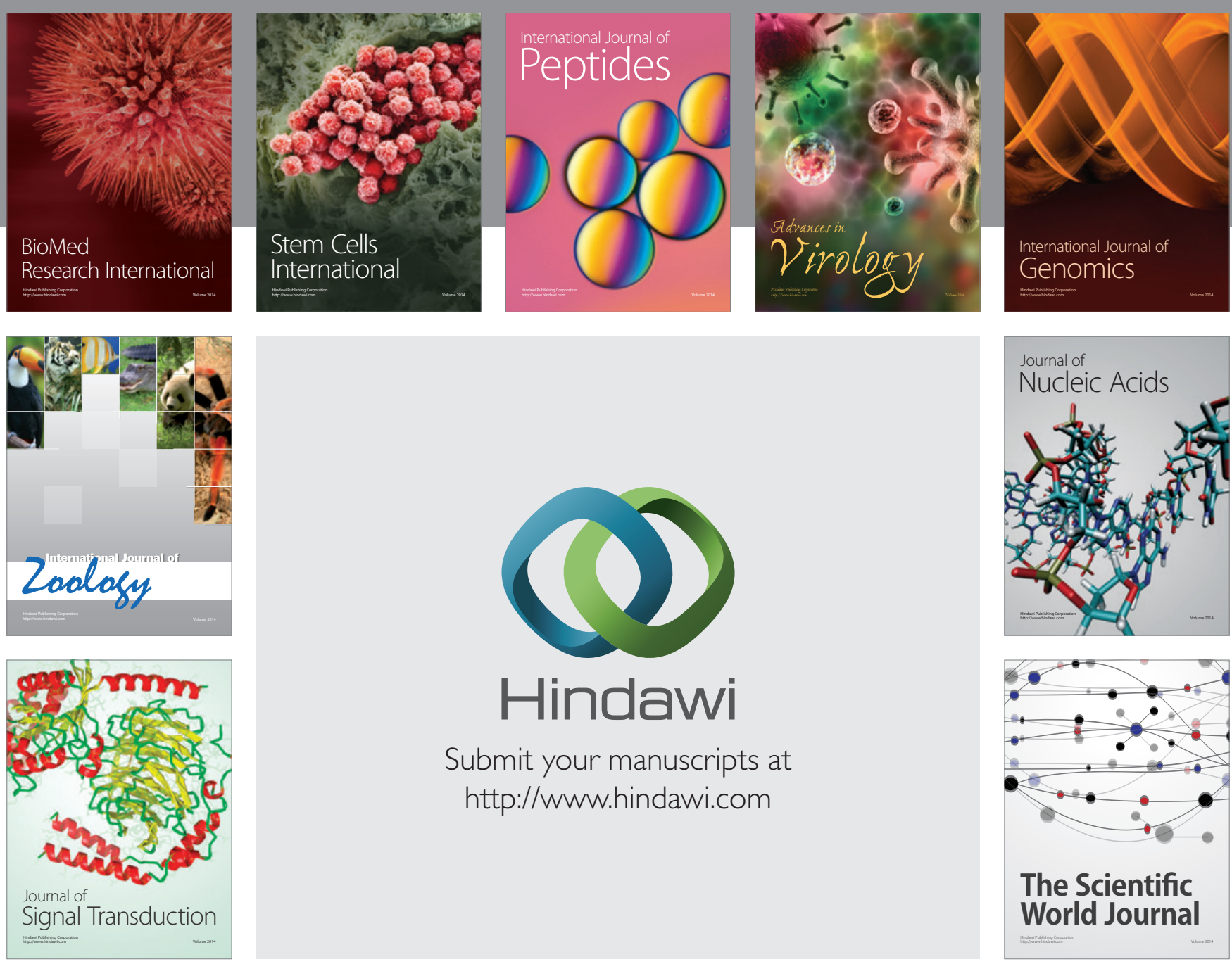

Submit your manuscripts at

http://www.hindawi.com
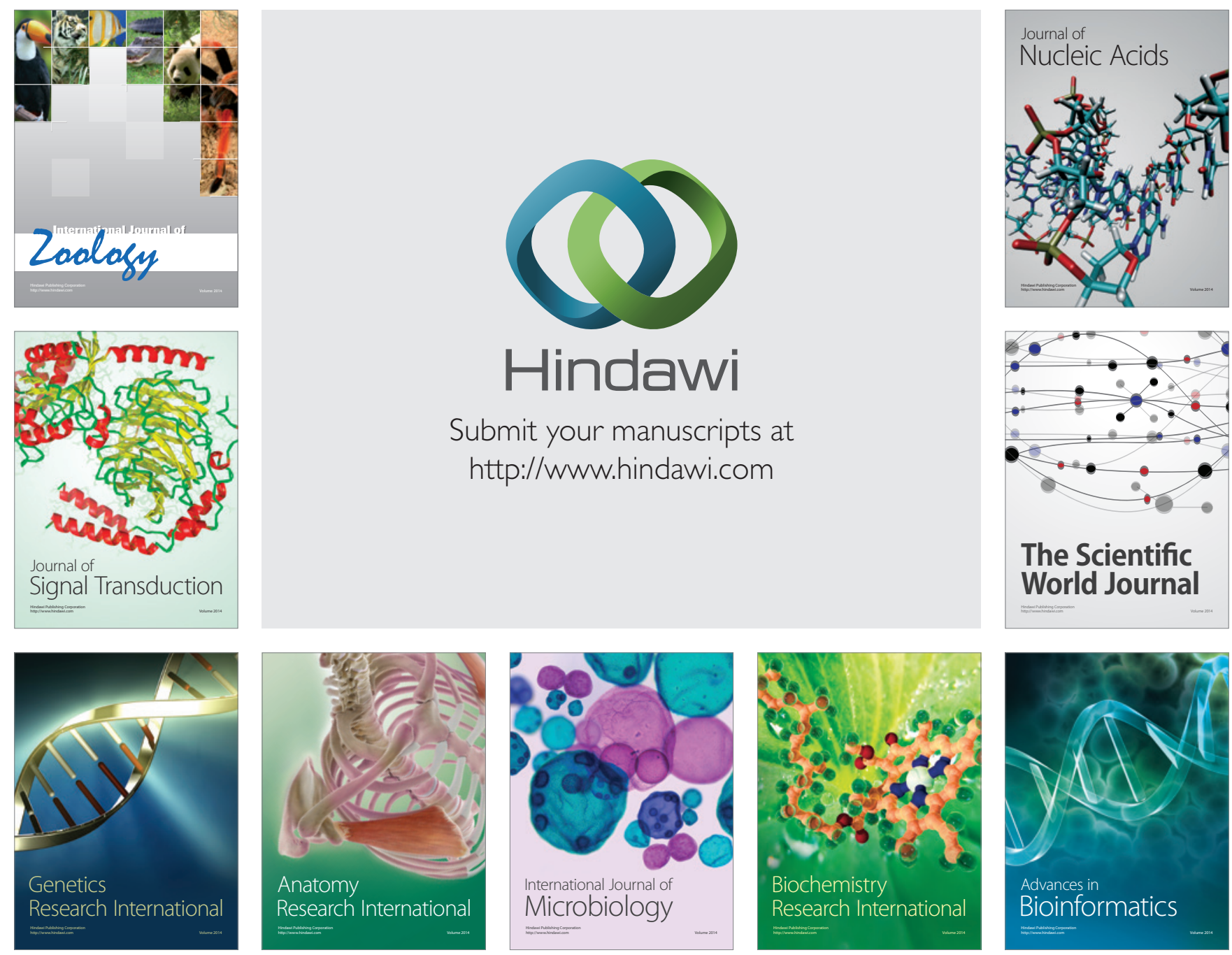

The Scientific World Journal
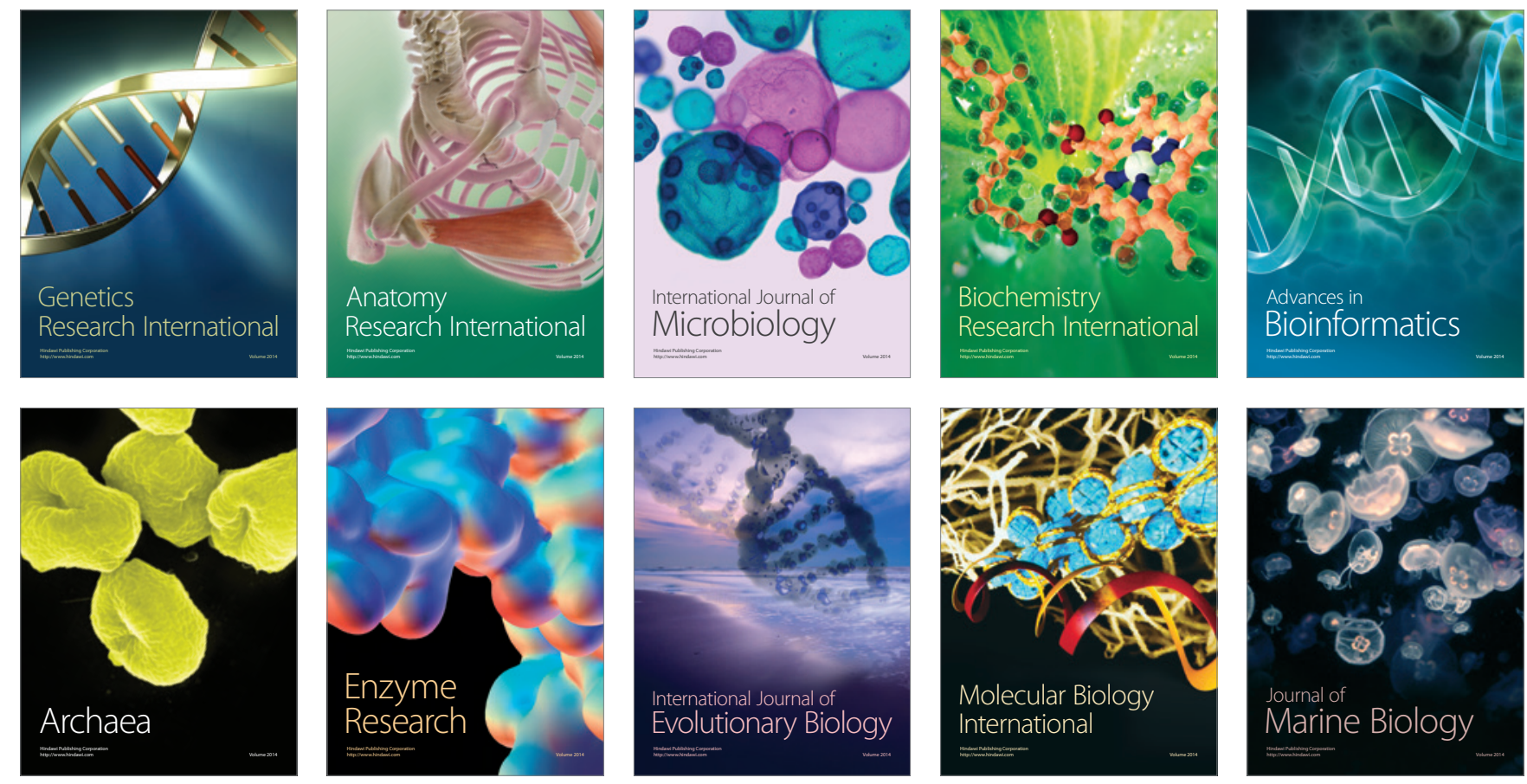